\title{
What in the world is educational technology? Rethinking the field from the perspective of the philosophy of technology
}

\begin{abstract}
Technology has been an important influence on the development of education. However, very little research in Educational Technology considers this history, and even less questions it. In this paper, we argue that our understanding of educational technology should be informed by the philosophy of technology - a field that has attempted to explore what these historical developments mean. This paper focuses on the ontological turn in philosophy and the technological thought of Marx and Heidegger. This is used to propose a foundation that can help researchers rethink educational technology, expanding research to account for humaneducation, human-technology and education-technology relations. It is proposed that humaneducation relationships should make students 'become what they are', highlighting their subjectivity rather than concentrating on information. Human-technology relationships can change the focus of design practice, so that technology is not merely seen as an efficient tool, but something 'handy' for peoples' educational needs. Education-technology relationships explain how technology can shape education, and re-introduces the idea of 'techne' as something to be valued in education.
\end{abstract}

Key words: philosophy of technology, educational technology research, relational thinking

\section{Introduction}

Technology is not only important in the development of contemporary society, it is arguably part of what sets humanity apart from even our closest hominid relatives (d'Errico, 2007). Unsurprisingly, then, technology has always contributed to debates about education, as well as influencing contemporary education through the creation of technological resources and new learning modes (Cuban, 2001). This has opened up new times and spaces for education, offering new possibilities for students' participation (Esposito et al, 2013).

Dusek $(2006,31)$ defines technology as hardware, rules and systems: not merely visible material, but also their integration with invisible and social elements. This view has shaped the development of educational technology, both as an area of research and a form of educational practice, so that it includes instructional tools, resources and also approaches that draw on technological discourse to frame and explain educational dynamics (Perrotta and Evans, 2013).

The emergence of new technology inevitably prompts further research in educational technology (Mayes, 1995). For example, mobile devices were a popular focus for the field for over a decade (Chiang et al., 2016). This has led to waves of educational technology research, emerging endlessly and often repetitively in response to new technological dvelopments. However, the field rarely reflects on these patterns, so it is not clear what (if anything) gives educational technology coherence or integrity during this relentless pursuit of the new. 
This paper argues that the philosophy of technology could provide helpful foundations for the field. To make this argument, firstly, reviews of the field itself are presented. Then, ontological and epistemological developments in philosophy, and in particular in the philosophy of technology, are reviewed. These are used to propose a framework with which to understand educational technology. This framework, which draws attention to humaneducation, human-technology and education-technology relationships, is then discussed in order to illustrate concerns and implications that follow from it.

\section{Reviewing the field of educational technology}

The scope and definition of 'education technology' are still debated. While some discussions consider practices and educational change as well as devices (see e.g. Januszewski \& Persichitte, 2008), much research is narrower in focus, so the term has become 'synonymous with such tools as computers, the Internet, mobiles and tablets and such issues as instructional design, mobile learning, social networking and open education resources' (Latchem, 2014). This has resulted in an unhelpfully narrow and instrumental body of research (Friesen, 2003).

Czerniewicz's review of the field (2010) confirms that no single, unifying narrative brings all this work together. Research draws on many different traditions and concepts, some of which are in tension with each other, and the field has been described as being more strongly oriented towards shared problems than shared foundations. Oliver (2013) similarly points to the absence of theories of technology within the field, resulting in impoverished explanations of how technology contributes to learning.

The Association for Education Communications and Technology offered an influential definition of the field (see Braden, 1995), cited over five thousand times. This proposes that educational technology consists of the integration of three things: visual instruction, personalized systems and systematic methods of evaluation. This tradition views educational technology as the application of technology to improve the efficiency of education through the new or improved functionality. This echoes wider discussions about the 'evolution' of technology (e.g. Arthu, 2009). It remains driven by technological developments, with social considerations primarily understood as consequences. It is unsurprising that practitioners within this paradigm therefore prioritise case studies where new technologies are demonstrated (Czerniewicz, 2010).

However, this kind of work is limited to instrumental concerns, remaining disappointingly apolitical and a-social (Selwyn, 2013). Unsurprisingly, it cannot explain failures or limitations. Cuban, for example, explored how computers have been 'oversold and underused' in education $(2001,179)$, identifying many unexpected outcomes or 'revenge effects' that followed from the relentless promotion of technology. This pattern continues today: for example, although MOOCs gained widespread popularity for their flexibility and convenience, up to $90 \%$ of students drop out due to insufficient prior knowledge and having no-one to turn to for help or support (Hew and Cheung, 2014). New technologies may be hyped relentlessly, e.g. through the New Media Consortium's Horizon Reports, but many predictions fail, and few technologies achieve the promised impact (e.g. Sergio et al, 2011).

Similarly, the way in which people do educational technology - how people make use of technologies in education - also assumes evolutionary progress. Christensen argues (2008) they are typically 'sustaining technologies', organizationally adapted to streamline and extend prevailing practices, rather than challenging fundamental suppositions, routines or roles (Thumlert et al., 2015). 
This dominant, instrumentalist view of educational technology can be understood as a consequence of 'substantial thinking' - an idea that will be explored further below.

Substantial thinking considers educational technology to be the combination of educational and technological factors that play a supporting role in activities. In this tradition, possible futures seem to emerge by identifying the new functionality novel technologies offers education.

However, this is not the only way of thinking about the relationship between technology and education. In the next section, perspectives from philosophy will be introduced that provide alternatives.

\section{The ontological turn and epistemological perspectives}

Ontology is the theory of what exists and is the foremost concern of metaphysics, which addresses questions about being and the nature of reality (Ladyman, 2007, 303). Aristotle was an important early influence on this area of work; he focused on beings rather than the idea of 'being' in a more general or abstract sense, and so proposed that substance should be the first category of being. Later, building on Aristotle's 'substantial' ontological position, Descartes proposed scepticism about taking the evidence of the senses at face value, arguing instead that 'I think, therefore I am' should provide the foundation for ontological thought, provoking the rise of mind-body dualism. Although this helped to highlight human subjectivity, it reinscribed the difference between 'being' and 'beings': 'human' and 'the world' became independent and separated substances, and later philosophers believed that as a result, human 'being' had been forgotten (Heidegger, 1996). At the beginning of the $20^{\text {th }}$ Century, philosophers therefore returned to questions about what it meant to be human, leading to a further ontological turn in philosophy. Heidegger (1996) proposed, for example, that the fundamental constitution of human being was 'being-in-the-world': the world of humans is a 'with-world', and that being human means being-with others, so the structure of human existence is considered as coexistence. Philosophers following Heidegger therefore focus on the experience of human's being, rather than considering it in terms of substance.

These ontological developments led to an associated epistemological turn, from substantial thinking to relational thinking. Substantial thinking, following Aristotle, proposed that things pre-existed analysis: substance was prior to thinking about those things. This 'substantial prior' model dominated thinking for centuries, shaping the natural sciences and the development of society. However, with the development of areas such as cybernetic science and perspectives such as feminist studies of science and technology, the tradition of philosophical dualism that set the abstract, thinking subject apart from the material objects of study was challenged (see, e.g., Haraway, 1988).

The problem identified by these new perspectives was that substantial thinking ignored the relations between things and did not provide a good account of dynamic developments. An alternative is to explore how relationships between things result in the characteristics that we perceive (Dépelteau, 2008). The implication of this, applied in the context covered by this paper, would be that the qualities that we attribute to educational technologies, for example, are not inherent to specific devices, but are instead the result of many factors in combination, including the relationships between these devices and their users.

Relational thinking thus emphasizes the 'being' of the things, understood in terms of situated practices, rather than the abstract 'to be' that results from 'substantial prior' thinking (Heidegger, 1959; Whitehead, 1929). While substantial thinking is a kind of vertical thinking 
- emphasizing hierarchy - relational thinking is a kind of lateral thinking - emphasizing diversity, and looking for commonalities.

\section{The philosophy of technology}

An important special case of the shift from substantial to relational thinking can be seen in the philosophy of technology, which - Surry and Baker (2016) have argued - is of direct relevance to work in the field of educational technology.

Technology can be understood a common, material thing that pervades today's society; arguably, it is to humans, just as the web is to the spider. The philosophical investigation of technology itself was neglected until the industrial revolution. Early thinking considered it as a significant power affecting society and following its own intrinsic developmental logic (Wu, 2009). However, this thinking has developed through the work of philosophers such as Marx, Heidegger and Ihde.

Marx (1964) argued for the importance of new technologies in promoting the development of society. He did not describe his work as 'philosophy of technology', but focused on technological issues connected with human nature and social development. Marx considers that technology is 'the external revelation of man's essential powers', and that 'the history of industry and the objective existence of industry as it has developed is the open book of the essential powers of man, man's psychology present in tangible form' (Marx, 1975, 354). Marx thus sees technology not only in terms of visible materials (as in substantial thinking), but also the social relationships formed by the production process. For example, an industrial production line creates different social relations from those prevalent in the agricultural age; this not only develops the division of labour within the production process, but also the wider development of industrial social relations. Marx also considered technology as the extension of human body, so that people equipped with different technologies should be understood as being techno-human (Allenby and Sarewitz, 2011) - an idea reflected in several strands of contemporary educational technology research (Bayne, 2015). Both these ideas emphasise the relational nature of technology use.

Technology is also important in Heidegger's work. Heidegger's early thinking (1996) developed the idea of the 'useful thing', which is 'something in order to ...'. This led to the differentiation of two kinds of relations between humans and useful things - 'ready-to-hand' and 'present-at-hand'. For example, a pair of suitable glasses on my nose would be ready-tohand for me, because their presence contributes to my actions, rather than disrupting them. However, if they were broken, I might feel uncomfortable. The glasses then become presentat-hand: I am aware of their presence, which disrupts my activities. This sense of distance is important throughout the history of educational technology; it can be seen, for example, in the challenges of technology integration in schools (e.g. Zhao et al, 2002), and explains the feeling that research is preoccupied with fixing the integration of emerging technologies, not understanding the vast array of technologies that are already integral to educational work (e.g. Mayes, 1995).

Heidegger argues further that the tool at-hand shows the world: the context of useful things creates 'a totality that has continually been seen beforehand in our circumspection', defining the world as we live in it (1996,70). Consequently, peoples' use of technology must be understood from a situated perspective, not reduced to a focus on technology in isolation. In Heidegger's later thought, 'the world' becomes the central topic, and Heidegger discusses this in a way that includes technology. His tendency, however, is to do this with reference to 
specific handmade things, rather than complex or industrial products (Latour, 2004). These crafted artefacts are considered as a 'gathering of the world'. For example, Heidegger sees 'the jug' not only as a vessel, but as being rich in meaning in a way that verges on the mystical: its 'presencing is the pure, giving gathering of the onefold fourfold into a single time-space, a single stay' (Heidegger, 1971, 171); 'each thing stays the fourfold into a happening of the simple onehood of world' $(1971,178)$. From this perspective, technology is understood relationally: it reveals the world and shows itself by its being in the world, where 'the world' involves the dwelling of the technology, human and other elements. Heidegger's analysis moves beyond the duality of subject and object, emphasizing the relations between human and technology. This kind of perspective has been uncommon in educational technology, but is important as a way of opening up research to new kinds of insight (Friesen, 2003).

Ihde developed a post-phenomenological position that builds on Heidegger's work, referred to as the phenomenology of technics. Ihde (1990) distinguishes four kinds of relations between humans and technology: 'embodiment relations', 'hermeneutic relations', 'alterity relations', and 'background relations'. Embodiment relations are where technology becomes transparent and is incorporated into human's perceptual-bodily experience. Just as a mobile phone might become a taken for granted artefact, technology can bring us closer but simultaneously withdraw from our attention. Importantly, however, Ihde proposes that technology not only extends peoples' physiological functions but also deepens their understanding of the world. For example, when used to observe the world, a telescope can magnify perception through its optical function; this not only makes certain observational tasks more efficient, it also changes peoples' ability to know the world, changing our relationship to it. From this perspective, humans, technology and the world constitute a relational triangle in which every factor has equal status and interrelates with the others (Weiss, 2008).

This triangular set of relations has become central to current debates in the field of philosophy of technology, influenced by post-phenomenology and the empirical turn (Ihde, 1990; Verbeek, 2008). This perspective emphasizes that technology is not simply a neutral means to a more efficient end, but is instead an intervening factor in human activities and our understanding of world. That is to say, when there is a change in the relationships between human and technology, the relationship between human and the world changes too.

\section{The nature of educational technology}

Educational technology is important in promoting the development of education, due to the widespread application of educational media and technological methods; consequently, it warrants careful attention (An and Li, 2014).

According to Hegel (1967) and Heidegger (1977), what is 'familiarly known' is not properly known. This means that our familiar, everyday experiences with technology are not sufficient to understand the nature of technology. We cannot rely on everyday, common sense discussions as the basis for research; instead, we need to develop a position that allows more disciplined insights to develop.

A common sense understanding of 'educational technology' might suggest that technology consists of specific activities or materials, but this risks falling back into substantial thinking. The nature of educational technology does not lie in these specific instances. 
Drawing on Ihde and Weiss, a more considered discussion of the nature of educational technology is enabled by considering the relations among education, technology, and humanity: specifically, human-education human-technology, and education-technology relations. These three sets of relations create a framework which will be explored further here.

\section{Human-education}

Humans may be acting beings, but unlike animals that are specifically adapted to their place in the world, they act in ways that are undetermined by their nature or culture - in other words, they have freedom, including the freedom to give in to external pressures, give up or otherwise act in ways that are detrimental to themselves or others (Gehlen, 1988). According to Kant (1900), a person is the only being that needs education, and (s)he can only become a person through education, which changes our animal nature into human nature and continues to improve it. Therefore, the purpose of education is to promote the development of students; the question of exactly how to cultivate the student then becomes central to the humaneducation relationship.

In public debates, policy and some research, education is sometimes reduced to a standardized knowledge transfer process. Students are positioned as outside of education, and are treated as its object. As Freire (2005) famously proposed, much educational practice reveals its fundamentally character as an act of 'depositing' information, leading to the "banking model" of pedagogy. Here, the students' task is to receive, memorize and repeat content from teachers. This approach reflects substantial thinking, wherein knowledge exists independently of the students. The consequence is that the relation between education and students is a subject-object binary. Even popular pedagogical approaches in the last two decades, such as outcomes-based education and standards-based education, embody a substantial view of education. Specifically, instructional objectives focus on the knowledge or competences which students should achieve by the end of the process, assuming that these exist independently of the individuals expected to engage with them. Direct instruction and explicit teaching are the main approaches of such teaching (Donnelly, 2007), even when there is no 'one-size-fits-all' model of students' learning (Willett, 2018). Therefore, we can argue that this approach ignores students' subjectivity,limiting the possibility of education becoming part of the world in which the student lives.

If we start instead by assuming an inherent relationship between humans and education, then rather than filling students with knowledge, education should meet different individual needs. Students' subjectivity should be highlighted, and they should be treated as autonomous learners. There are many historical examples of this orientation to education. Kant $(1900,30)$, for example, argued that education consists of instruction in the practical matters of life and moral character, teaching a person how to live as a free being by developing students' social and moral abilities. Dewey, argued that students' growth is 'a constant reorganizing and reconstructing of experience'; so learning should be an active and constructive process of meaning making through co-constructions with others (Dewey, 1916, 76; Reich, et al., 2016). More recently, inquiry-based learning emphasizes active participation and student's responsibility for discovering knowledge (Pedaste, et al., 2015), focusing on students' organisation of their learning and collaboration with others, developing their social abilities and moral characters.

A consequence of this view is that education should be generative, rather than closed and standardised. Complexity theory, for example, proposes that education is open, dynamic and 
relational, and its elements constitute and interact with each other (Mason, 2008). There are various uncertainties and ambiguities in educational processes that are situational, and which have different temporal and spatial characteristics. For example, students' learning preparedness and teachers' instructional styles vary, so any pre-specified educational process will inevitably ignore rich alternatives, and will vary in appropriateness from person to person. A Chinese educational proverb proposes, 'there are unlimited methods of teaching available that are worth selecting': different pedagogical approaches have been developed for use with students in diverse educational situations, so the question of which to adopt should reflect teachers' engagement with learners rather than being pre-determined. Education then should be neither teacher-centered nor student-centered, but should be based on teacherstudent engagement and consultation. Education as a co-constructive process, recognising the histories, situations and dispositions of all those involved, respects students' individual differences and teaches them in accordance with their aptitude.

Heidegger explored the relationship between humans and the world using the concept of $D a$ sein, understood as 'being-in-the-world'. He argued that 'the world', is an ontic concept signifying the totality of beings, which designates the ontological and existential conception of worldliness (Heidegger, 1996, 60-61). Heidegger further argued that since humans are temporal beings, their 'being' is not fixed; so 'Da-sein is what it becomes' (see Thomson, 2004). Consquently the character of things is emergent, not pre-determined: 'men by dwelling attain to the world as world. Only what conjoins itself out of world becomes a thing' (Heidegger, 1971, 180). This world concept has important implications for the relation between human and education.

For students, education (which is an important part of the world they dwell in) should not be designed following a kind of instrumental rationality to shape their knowledge and behaviours in pre-specified ways; instead, it should be designed to reveal human nature. According to Heidegger, education should promote thinking and reflection, and adopt an open orientation towards the diverse ways in which students develop; it should become an 'openness to mystery' (Wrathall, 2011). Designed in this way, education could encourage students to develop 'Gelassenheit' (an openness to what is) and 'Besinnung' (thoughtful engagement with what is strange or surprising) (Huang and Liu, 2016). This demands a focus on dialogue between teacher and student, not efficient information transmission. As Heidegger argues, in a discussion of poetry, $(2000,56)$, human beings are a conversation - in that "man's (sic) being is grounded in language; but this actually occurs only in conversation". Such conversational dialogue has since been considered as a dynamic game of references, of signs, that allows new paths of thought (Pezze, 2005). Teachers and students have their education encounter in dialogue, in which the united reflection and action of the dialoguers is addressed towards the world, understood not as a pre-existing source (as in 'substantial prior' approaches) but as something to be transformed and humanized (Freire, $2005,88-89)$. This is an idea that was prominent in educational technology for around two decades (e.g. Laurillard, 1993; 2013), although it is less explicit in current research. If students' growth is understood in this way - as a process of revealing, not memorizing passively - education can encourage them to develop in ways that are authentic, so that students can 'become what they are' (Thomson, 2004).

\section{Human-technology}

As discussed, humans can be thought of as technology-using beings. We cannot lead nontechnological lives, because we are inherently technological organisms (Mitcham, 2006, 30). 
From this perspective, students simply cannot learn without involving technology. However, not all technology use has the same character, and as a result, different human-technology relationships arise.

Substantial thinking suggests that educational technology involves standardized, nonpersonalized interventions external to students, and is about tools for learning. The relation between students and technology, therefore, would appear separate and incidental; this suggests technology is like a radio broadcast: it is pushed at us; we receive or reject it; but cannot affect its content. This leads to standardized 'dose-response' models of educational technology, and simplistic questions about whether technology 'works' or not, decontextualized from questions about for whom it works, under what circumstances, etc (Oliver and Conole, 2003). For example, although MOOCs are widespread, there are still high dropout rates; the same technology works for some people but not others. Similarly, 'quantified-self' technology used to collect and analyze students' learning data offers learning benefits; but such data-centric approaches are not necessarily fit for all students' learning (see Eynon, 2015). As such, if we wish technology use to achieve better effects, technological applications should conform to students' experiences, knowledge and backgrounds.

We can turn to relational thinking to elaborate this alternative understanding of the humantechnology relationship in the field of educational technology. Although technologies can contribute to changes in students' approaches to learning, they require recontextualizing in the specificities of students' own practices. Over time, however, these local acts of contextualisation can be reflected in the development of more systemic, shared developments. Simondon argues that technologies are adapted to their multiple milieus by concretizing advances, which means establishing synergisms between technologies and the various environments in which they are used (Feenberg, 2002, 186). Thus some new learning technologies can indeed 'offer students learning opportunities that facilitate flexible teaching and learning which in turn are designed to fit in with the particular needs of students' (Clegg and Steel, 2002). For example, from the perspective of embodied cognition, learning is deeply related to human's sensorimotor system and the body's interaction with the physical environment, and technologies that can effectively combine virtual and physical elements create the immersive, whole-body interactive conditions which could enhance learning (Lindgren, et al., 2016). Therefore, in embodied learning environments, the boundary between the student and technology can be blurred by the interactive and immersive experience of technology, which involves the use of the student's body as part of the control mechanism. In this way, the technology can be integrated with both body and mind, and these factors can improve learning together.

The human-technology relationship is a central concern for Heidegger. Following Heidegger, as 'useful things', technology should be ready-to-hand for students' learning. That is to say, when exerting its functions effectively, educational technology should withdraw from being the focus for educational information, or from being an explicit consideration in students' learning processes - like the famous hammer that Heidegger uses as an example, where fluent use allows the builder to focus on the nail being hammered rather than the tool being used. Moreover, the more 'handy' relations are between students and educational technology, the more educational technology can be useful. Therefore, the relationship between students and educational technology could be characterized in terms of handiness and humanization, so as to improve not just the efficiency of students' learning, but also its quality and character. According to Ihde, technologies should fit the application, and this is achieved by balancing 
two desires that arising from the experience of embodiment relations between humans and technology. The first is a wish for total transparency and embodiment: for the technology to truly 'become me'. The other is the desire to have the power that the technology makes available, which transforms our relationship with other parts of the world in which we are interested (Ihde, 2003, 140). Therefore, the most advanced technologies will not always lead to the best learning effect; the best technology is just like the hammer in Heidegger's hand, which draws no attention to its existence and is easy to use for the work at hand.

One interesting consequence of this is that the application of educational technology can develop the relationship of being-with between the student and technology. That is, the technology is not merely a means to an end for the student; instead there is a symbiosis between the student and technology, which constitute the subject of the learning process together. In this sense, following Idhe, when the technology 'becomes me', the student's being is developed, which may be important in its own right. (An obbvious example of this might include musicians' symbiosis with their instruments, which may be an important outcome of musical education.) We should therefore move beyond deterministic assumption that technologies possess inherent qualities, and are capable of having particular 'impacts' or 'effects' on learners if used in correct manners (Selwyn, 2010), and consider instead how technology use might enable students to develop their relationships with the world, and with technologies themselves.

\section{Education-technology}

In popular discussions of education, it is often taken for granted that technology will promote educational development. However, this kind of technological determinism is an oversimplistic account of educational technology, in which technology is presented as if it causes particular educational outcomes; it provides an imbalanced understanding of the relationship between education and technology (Oliver, 2011). This over-simplification is a result of substantial thinking, which would suggest that the technology is simply a tool or means in the educational process that can be entirely detached from education itself.

Moreover, the consequence of this account is that the traditional educational model is not changed but reinforced by technologies, which are positioned as more powerful means to transmit knowledge to students. For example, Friesen (2009) has argued that the rapid emergence of the Internet was refashioned through virtual learning environments developed by universities, which reinforced the traditional functions and identities of university personnel. Although the application of new technologies seems to have brought infinite hope to educators, there is instead a 'slow revolution' in educational processes (Cuban, 2002), and some educational applications could be thought of as 'old ideas, new technologies' (Becker and Birdi, 2018). Instead, care should be taken so that the role of technological applications in education is not exaggerated. To avoid over-simplifying, the relationship between education and technology must be rethought.

From the perspective of relational thinking, education and technology can be integrated to improve students' learning. According to Latour (2005), education and technology can constitute an actor network in which each interacts with the other. That is, technology can shape education, but it is important to recognize that education also chooses and adapts technologies. Technology is not produced in a cultural vacuum, but is instead a cohesion of various existing kinds of social relations and approaches to communication. Technology, therefore, can have an effect on education by reflecting this history in its design. Surry and Baker (2016), for example, have drawn on perspectives from the sociology of technology to 
show how the links between technology and communities can be reciprocal, rather than deterministic. However, technology adoption can have unanticipated consequences; it is not always predictable or consistently positive. For example, open educational practices, supported by networked and digital technologies, promoting decentralization and democratization of control over knowledge production, encouraging higher education to operate in ways that are flexible and permeable (Oliver, 2015). In this way, the formative influence of technology can encourage education to become more individualized and go beyond homogeneity (Lewin and Lundie, 2016). However, Clegg and Steel (2002) have argued that technologies which had been designed to be flexible can instead create inflexibility, resulting in teachers and students driving themselves towards constant participation, pushing higher education towards a Post-Fordist relationship with students.

According to Heidegger, technology not only reveals but also dwells in the world, and the relation between technology and the world is a fundamental part of humanity's ways of being. What is more, in Heidegger's later thought (1977), he questioned the essence of modern technology, which is conceived of as the 'Ge-stell' - the view of technology as a mode of existence, which frames the world as a 'standing reserve' to be used efficiently. By contrast, he regarded 'art' as the saving power against the violence of technology. Heidegger also highlighted the Greek concept of techné, which was thought of as a way of revealing and belonged within poiessis. In considering the relationship between Education and technology, therefore, we should resist the danger of modern technology enframing students, teachers and knowledge as a 'standing reserve' to be processed, and instead consider the expressive way in which techné can present an alternative educational horizon.

According to Heiddegger, techné is a mode of rendering beings manifest (1998, 259). From this perspective, techné does not frame education, but leads to authentic education by revealing ways of being in the world. Heiddegger's discussion of techné in the work of art $(2002,22)$ - the work art does, the 'setting forth' that it achieves - highlights how art creates worlds that shape how we act, think and make sense of things; it creates possibilities for some things to happen, and by implication, distances us from others. In this way, it opens up a world, keeps it abidingly in force and gathers a unity of relations around itself. Thus techné, understood not just as the technical object but as craft and art that invites some ways of being and distances others, means that educational technology not only manifests itself as visible material products, but also discloses new worlds of education, inviting specific kinds of engagement between teachers and students in education.

This means that creating new educational technologies is generative of new educational ways of being in the world, not merely a technical fix that enables an established process of education to proceed more efficiently. For example, the inspirational presentations given by teachers can invite students to grow by reconsidering their relationship to subject knowledge. Games are often considered to be motivating, and are evaluated against whether they accelerate improved performance on standardized tests - but they can also invite students to rethink their identities, interactions and interests (Faican and Jaen,2020). Such develops could be understood not just as a novelty or a technical fix, but as an opportunity for new kinds of authentic disclosure. Education, therefore, should not be shackled by the introduction of modern technology, limited to discussions of efficiency with staff and students treated as 'standing reserves' to be processed, but could instead offer new ways for them to be-in-theworld, by opening up and sustaining new spaces for education. 


\section{Discussion}

Introducing perspectives from Marx, Heidegger and Ihde allows educational technology to be rethought relationally, challenging substantial thinking. Rather than being an independent causal force that affects education, educational technology can be rethought in terms of human-technology, education-technology and human-education relationships. This reframes our understanding of educational technologies: there is no longer any simple, mechanical 'impact', but instead, purposeful action and negotiated meanings (see Oliver, 2011).

Understanding the essence of educational technology in this way has implications for the practical development of educational technology, as well as for research. Substantial thinking treats educational technology as merely a kind of tool, resulting in simplistic models of technology effects. For example, the application of technology is usually assumed to improve learning (Kirkwood and Price, 2014). What the relational re-framing clarifies, however, is that technology is not an external influence, but part of a cultural and historical context. We can no longer assume that introducing new technology will make education 'better' in some way - or even that it will 'work' (as previously understood). From the perspective of relational thinking, adding technology does not solve problems, but invites change. Aspects of this can be seen, for example, in versions of instructional design where the design process approaches technology not as a solution, but instead as an intervention which 'transforms the world from its current state to a preferred state' (Zimmerman, 2007). Technology thus acts as a 'mediator' (Ihde, 1990) between students and education, changing their relationship.

This means that education can be designed to invite new kinds of relationships between students and technology, not just accelerate existing ones. For example, virtual worlds, offering open-ended and dynamic environments, provide opportunities to construct new kinds of representations of knowledge, offering generative possibilities for education. The design of technologies therefore alters through relational thinking, foregrounding the possibilities of open-ended and dynamic educational uses of technology rather than questions about efficiency. Minocha and Reeves (2010), for example, outlined principles for the design of 3D learning spaces focused on the relations among students, pedagogy and learning spaces in Second Life. Similarly, 3D visualizations can enable students to represent knowledge in new ways, introducing students to chemical or biological molecular structures through modelling, making learning richer and more interesting. Logo provides an interesting historical example of such shifts: it promoted mathematics teaching that encouraged embodied thinking and understanding. However, the transformative vision designers had for Logo did not cause a revolution just through the design; this was itself mediated by the wider socio-historical context, including school curricula, commercial interests, national policies, marketing decisions and the influence of other programming languages (Agalianos, Whitty \& Noss, 2006).

\section{Conclusion}

Research in educational technology has typically focused on pragmatic questions and on understanding the features of new technologies. This has resulted in a limited understanding of what educational technology is, contributing to inconsistencies and incoherence in the field. A richer account can be developed by drawing from discussions within the philosophy of technology. The work of philosophers such as Marx, Heidegger and Ihde explored the relationships between technology, humans and the world. In this paper, this foundational thinking has been used to generate a framework that can be used to shape educational technology. 
Educational technology has traditionally been shaped by 'substantial thinking'; this conforms to common sense, but is limited conceptually. It frames the relationship between education and technology as external and mechanical, emphasising technological factors as causes that can overcome perceived problems in educational practice, and resulting in the alienation of technology from education (Reveley, 2013).

Relational thinking, however, provides more sophisticated accounts of the relationships between education and technology. It reframes educational technology as a dynamic and complex enactment of new relationships, offering new perspectives on the field. These can be prompted by the three-way framework outlined in this paper. This draws attention to humantechnology, technology-education and education-human relationships, requiring researchers to ask new kinds of questions about educational uses of technology, including questions rarely asked within this field about the purpose of education itself. Specifically, the philosophical framing suggests that human-education relationships should enable students to 'become what they are'; students' subjectivity should be highlighted, and education thought through in terms of what it means for them. The human-technology relationships draw attention to the ways in which technology should be 'handy', so that it is ready-to-hand in the service of people's educational needs. At the same time, the idea that technology is an integral part (for good or ill) of what 'being-in-the-world' means, raises important questions about what it means to be human in contemporary society. These education-technology relationships do contain the conventional concerns about how technology shapes education, but also prompts complementary new questions about how techné can be applied in education. Taken together, we can move on from thinking about what technology 'does' to education, and start to think instead what '-in-the-world' technology is, and what this means for the 'being-in-the-world' of learners, teachers, educational designers and researchers.

\section{References}

Agalianos, A., Whitty, G., \& Noss, R. 2006. The social shaping of Logo. Social studies of science, 36 (2), 241-267.

Allenby, B., and D. Sarewitz. 2011. The Techno-Human Condition. Cambridge, MA: MIT Press.

Arthur, W. B. 2009. The nature of technology: what it is and how it evolves. London: Penguin.

An, T., and Y. Li. 2014. "On theoretical prospect of educational technology from the perspective of philosophy of technology". Educational Research 4(2014):37-42.

Bayne, S. 2015. "What's the matter with 'technology-enhanced learning"'? Learning, Media and Technology, 40, (1): 5-20.

Beckera, R., and A. Birdib. 2018. "Flipping the classroom: Old ideas, new technologies." International Review of Economics Education 29(2018):1-5.

Braden, A. 1995. "Review of instructional technology: the definition and domains of the field." Educational Technology Research and Development, 43,(1): 81-83. 
Chen, J.Q., R. Salahuddin, P. Horsch, and S. Wagner. 2000. "Turning standardized test scores into a tool for improving teaching and learning: An assessment-based approach." Urban Education 35(3): 356-384.

Chiang, F.K., G. X. Zhu, Q.Wang, Z.F. Cui, S. Cai, and S.Q. Yu. 2016. "Research and trends in mobile learning from 1976 to 2013: a content analysis of patents in selected databases". Britain Journal of Educational Technology 47 (6):1006-1019.

Clegg, S., and J. Steel. 2002. "Flexibility as myth? new technologies and post-fordism in higher education". Proceedings of the networked learning conference. http://www.networkedlearningconference.org.uk/past/nlc2002/abstracts/sym/08jones/jones.p df.

Clow, D. 2012. "The learning analytics cycle: closing the loop effectively". Proceedings of the $2^{\text {nd }}$ International Conference on Learning Analytics and Knowledge.

http://oro.open.ac.uk/34330/1/LAK12-DougClow-personalcopy.pdf

Cuban, L. 2001. Oversold and underused: computers in the classroom. Cambridge, London: Harvard University Press.

Czerniewicz, L. 2010. "Educational technology-mapping the terrain with Bernstein as cartographer". Journal of Computer Assisted Learning 26 (6): 523-534.

d'Errico, F. (2007). The origin of humanity and modern cultures: archaeology's view. Diogenes, 54 (2): 122-133.

Dépelteau, F. 2008. "Relational thinking: a critique of co-deterministic theories of structure and agency." Sociological Theory 26 (1): 51-73.

Dewey, J. 1916. "Democracy and Education: An introduction to the Philosophy of Education.” New York, NY: the Free Press.

Donnelly, K. 2007. “Australia's Adoption of Outcomes Based Education: A Critique.” Issues in Educational Research 17 (2) :183-206.

Dusek, V. 2006. Philosophy of Technology: An Introduction. Malden: Blackwell Publishing.

Esposito, A., A. Sangrà, and M. Maina. 2013. Chronotopes in learner-generated contexts. A reflection about the interconnectedness of temporal and spatial dimensions to provide a framework for the exploration of hybrid learning ecologies of doctoral e-researchers. eLC Research Paper Series, 6, 15-28.

Eynon, R. 2015. "The quantified self for learning: critical questions for education." Learning, Media and Technology, 40(4): 407-411.

Faican, L.L., and J. Jaen.2020. "EmoFindAR: Evaluation of a mobile multiplayer augmented reality game for primary school children." Computer and Education, 149(2020). https://doi.org/10.1016/j.compedu.2020.103814

Feenberg, A. 2002. Transforming Technology: a critical theory revisited. Oxford: Oxford University Press. 
Fonseca, D., M. Nuri, E. Redondo, I. Navarro, and A. Sánchez. 2014. "Relationship between student profile, tool use, participation, and academic performance with the use of Augmented Reality technology for visualized architecture models." Computer in Human Behavior $31(2014): 434-445$.

Freire, P. 2005. Pedagogy of the Oppressed ( $30^{\text {th }}$ anniversary edition). New York: Continuum.

Friesen, N. 2009. Re-thinking e-learning research: foundations, methods, and practices. New York: Peter Lang.

Gehlen, A. 1988. Man: His Nature and Place in the World. New York: Columbia University Press.

Greenhow, C., and C. Lewin. 2016. "Social media and education: reconceptualizing the boundaries of formal and informal learning." Learning, Media and Technology 41(1): 6-30.

Haraway, D. 1988. "Situated knowledges: the science question in feminism and the privilege of partial perspective." Feminist Studies 14 (3): 575-599.

Hegel, G. 1967. The phenomenology of the mind, trans, J.B.Baillie. New York:Harper Torchbooks.

Heidegger, M.1959. An introduction to metaphysics, trans, Ralph Manheim. New Haven: Yale University Press.

Heidegger, M. 1971. Poetry, Language, Thought, trans, Albert Hofstader. New York: Harper and Row.

Heidegger, M. 1977. The Question concerning technology, and other essays. New York: Harper Torchbooks.

Heidegger, M.1996. Being and time, trans, Joan Stambaugh. Albany: State University of New York Press.

Heidegger, M. 1998. Letter on "Humanism”. In McNeill, W. (Ed), Pathmarks, 239-276. Cambridge: Cambridge University Press.

Heidegger, M. 2000. Elucidations of Holderlin's Poetry, trans, Keith Hoeller. New York: Humanity Books.

Heidegger, M. 2002. Off the Beaten Track, edited and trans, Julian Young and Kenneth Haynes. Cambridge: Cambridge University Press.

Hew, K., and W. Cheung. 2014. 'Students' and instructors' use of massive open online courses (MOOCs): Motivations and challenges." Educational Research Review 12(2014):4558 .

Huang, M., and T. F. Liu. 2016. "Education facing to Thinking of Heidegger and Its Theoretical Predicaments." Educational Research 12(2016):12-21. 
Ihde, D. 1990. Technology and the lifeworld. Bloomington and Indianapolis: Indiana University Press.

Ihde, D. 2003. "A Phenomenology of Technics.” In Readings in the Philosophy of Technology, edited by D. Kaplan, 137-160. Lanham: Rowman \& Littlefield Publisher, Inc.

Januszewski, A., \& Persichitte, K. 2008. A history of the AECT's definitions of educational technology. In Januszewski, A. \& Molenda, M. (Eds), Educational technology: A definition with commentary, 259-282. New York: Routledge.

Kant, I. 1990. Kant on Education. Boston: D.C. Heath and Co.

Kaplan, D. M. 2004. Readings in the philosophy of technology. Lanham, MD: Rowman \& littlefield publishers, inc.

Kirkwood, A., and L. Price. 2014. "Technology-enhanced learning and teaching in higher education: what is'enhanced'and how do we know? A critical literature review." Learning, media and technology 39(1):6-36.

Kozma, R. 1994. "Will media influence learning? Reframing the debate." Educational Technology Research and Development 42 (2): 7-19.

Ladyman, J. 2007. “Ontological, Epistemological, and Methodological Positions.” In General Philosophy of Science, edited by Theo A.F. Kuipers, 303-376. Amsterdam: North Holland

Latchem, C. 2014. "BJET Editorial: Opening up the educational technology research agenda." British Journal of Educational Technology 41(1): 3-11.

Latour, B. 2004. "Why has critique run out of steam? from matters of fact to matters of concern." Critical Inquiry 30(2): 225-248.

Latour, B. 2005. "Reassembling the Social". Oxford: Oxford University Press.

Laurillard, D. 1993. Rethinking University Teaching: A Framework for the Effective Use of Educational Technology. London: Routledge.

Laurillard, D. 2013 Rethinking university teaching: A conversational framework for the effective use of learning technologies. London: Routledge.

Lindgren, R., M.Tscholl, S.Wang, and E. Johnson. 2016. "Enhancing learning and engagement through embodied interaction within a mixed reality simulation." Computers \& Education 95 (2016): 174-187.

Marx, K. 1964. Economic and philosophic manuscripts of 1844. New York: International Publishers.

Marx, K. 1975. “Economic and philosophical manuscripts of 1844”, trans, Rodney Livingstone and Gregor Benton. London: Penguin.

Marx, K. 1976. Capital: a critique of political economy, trans, Ben Fowkes. London: Penguin. 
Mason, M. 2008."Complexity Theory and the Philosophy of Education.” Educational Philosophy and Theory 40, (1):4-18.

Mayes, T. 1995. Learning technology and groundhog day. In Hypermedia at work: practice and theory in higher education, edited by W. Strang, V. B. Simpson and D. Slater,21-37. Canterbury: University of Kent Press.

Mesle, R. 2008. Process-relational philosophy: an introduction to Alfred North Whitehead. West Conschocken, Penn: Templeton Foundation Press.

Mitcham, C. 2006. From phenomenology to pragmatism: using technology as an instrument. In Selinger, E. (Ed), Postphenomenology: a critical companion to Ihde, 21-33. Albany: State University of New York Press.

Ng, W. 2012. "Can we teach digital natives digital literacy?" Computers and Education 59 (3): 1065-1078.

Oliver, M., and G. Conole. 2003. "Evidence-based practice and e-learning in higher education: can we and should we?" Research papers in education 18 (4): 385-397.

Oliver, M. 2011. "Technological determinism in educational technology research: some alternative ways of thinking about the relationship between learning and technology." Journal of Computer Assisted Learning 27 (5): 373-384.

Oliver, M. 2013. "Learning technology: Theorising the tools we study." British Journal of Educational Technology 44 (1):31-43.

Oliver, M. 2015. "From openness to permeability: reframing open education in terms of positive liberty in the enactment of academic practices." Learning, Media and Technology 40 (3): 365-384.

Pedaste, M., M. Mäeots, L. Siiman, T. Jong, S. Riesen, E. Kamp, C. Manoli, Z. Zacharia, and E. Tsourlidaki. 2015. "Phases of inquiry-based learning: Definitions and the inquiry cycle." Educational Research Review 14 (2): 47-61.

Perrotta, C., and M.A. Evans. 2013. "Orchestration, power, and educational technology: A response to Dillenbourg." Computers and Education 69 (2013): 520-522.

Pezze, B.D. 2006. "Heidegger on Gelassenheit.” Minerva 10(2006) http://www.minerva.mic.ul.ie/vol10/Heidegger.html

Reich, K., J. Garrison, and S. Neubert. 2016. "Complexity and Reductionism in Educational Philosophy_John Dewey's Critical Approach in 'Democracy and Education' Reconsidered.” Educational Philosophy and Theory 48, (10): 997-1012.

Selwyn, N. 2010. "Looking beyond learning: notes towards the critical study of educational technology." Journal of Computer Assisted Learning 26 (2010): 65-73.

Selwyn, N. 2014. Education and 'the digital'. British Journal of Sociology of Education 35 (1): $155-164$. 
Sergio, M., D. Gabriel, E. Sancristobal, G. Rosario, C. Manuel, and P. Juan. 2011. "New technology trends in education: Seven years of forecasts and convergence." Computer and Education 57(2011): 1893-1906.

Surry, D., and F. Baker. 2016. "The co-dependent relationship of technology and communities.” British Journal of Educational Technology 47(1):13-28.

Thomson, I. 2004. "Heidegger's perfectionist philosophy of education in Being and Time." Continental Philosophy Review 7(4): 439-467.

Thumlert, K., S. Castell, and J. Jenson. 2015. "Short cuts and extended techniques: rethinking relations between technology and educational theory." Educational Philosophy and Theory, 47( 8): 786-803.

Tower, M., S. Latimer, and J. Hewitt. 2014. "Social networking as a learning tool: Nursing students' perception of efficacy.” Nurse Education Today 34(2014):1012-1017.

Verbeek, P. 2008. "Cyborg intentionality: rethinking the phenomenology of humantechnology relations." Phenomenology and the Cognitive Sciences 7(3):387-395.

Weiss, D. 2008. “Human—Technology—World.” Techne 12(2):110-119.

Willet, R. 2018. "Learning through making in public libraries: theories, practices, and tensions." Learning, Media and Technology, 43 (3): 250-262.

Wrathall, A. 2011. "We still need education in thinking: Heidegger's education in a technological age." Journal of Educational Studies, 7(1): 3-14.

Whitehead, A, N. 1929. Process and reality: an essay in cosmology. New York : Macmillan.

Wu, G.S. 2009. Lectures on the Philosophy of technology. Beijing: China Renmin University Press.

Zhao, Y., K. Pugh, S. Sheldon, and J. Byers. 2002. "Conditions for classroom technology innovations." The Teachers College Record 104(3): 482-515.

Zimmerman, J., J.Forlizzi, and S. Evenson. 2007. "Research Through design as a method for interaction design research in HCI". Proceedings of the SIGCHI Conference on Human Factors in Computing Systems. https://dl.acm.org/doi/pdf/10.1145/1240624.1240704. 